\title{
Sources of Growth and Variability in Production of Cumin in Jodhpur vis-à-vis Rajasthan
}

\author{
Kailash Chand Bairwa ${ }^{1 *}$, G.L. Meena ${ }^{2}$, P.C. Meena ${ }^{3}$, S.S. Burark², Hari Singh², \\ B. Upadhyay ${ }^{4}$ and P.C. Chaplot ${ }^{5}$
}

1:Ph.D. Research Work, Department of Agricultural Economics \& Management, Rajasthan College of Agriculture, MPUAT, Udaipur, Rajasthan, India

${ }^{2}$ Department of Agricultural Economics \& Management, Rajasthan College of Agriculture, MPUAT, Udaipur, Rajasthan, India ${ }^{3}$ Department of Agricultural Economics, Agriculture University, Jodhpur, Rajasthan, India

${ }^{4}$ Department of Agricultural Statistics, Rajasthan College of Agriculture, MPUAT, Udaipur, Rajasthan, India

${ }^{5}$ Department of Agronomy, Rajasthan College of Agriculture, MPUAT, Udaipur, Rajasthan, India

"Corresponding author: kailashiari@gmail.com (ORCID ID: 0000-0002-4278-3109)

Received: $11-07-2020$

Revised: $13-10-2020$

Accepted: $18-11-2020$

\begin{abstract}
Cumin production of Rajasthan and Jodhpur were kept a dominant position in Seed spices economy of the country. This study was attempt to present the comparative performance of cumin in Rajasthan and Jodhpur. For drawing a meaningful termination of Agri-Export Zones on cumin production in Rajasthan, the selected study period from 1991-92 to 2018-19 was divided into three sub-periods as Ex-ante AgriExport Zone (1991-92 to 2004-05), Ex-post Agri-Export Zone (2005-06 to 2018-19) and overall study period (1991-92 to 2018-19). The results of the growth analysis revealed that area, yield and production of cumin in Jodhpur was increased faster than Rajasthan and period-I. In case of instability, the production and yield of this crop in period-II were more instable than other two periods in Rajasthan and Jodhpur. The introduction of high yielding varieties has boosted up production Rajasthan especially in Jodhpur. During period-I the growth of output was contributed mainly due to increasing area under the crop. However, in period-II development of high yielding varieties have positive and significant effect on expanding production in Jodhpur and Rajasthan.

\section{Highlights}

(0 The area, production and productivity of cumin in Jodhpur was mounted up higher than Rajasthan.

( The production and yield of cumin was highly instable in period-II (2005-06 to 2018-19).
\end{abstract}

Keywords: Growth analysis, Cumin production, Output growth sources, Instability analysis

Rajasthan state is a predominant component in Indian bowl of seed spices. The coriander (Coriandrum sativum), cumin (Cuminum cyminum), fennel (Foeniculum vulgare), fenugreek (Trigonella foenum-graecum), ajwain (Trachyspermum ammi) and dill (Anethum graveolens) crops are collectively called seed spices. The profitability, short run period and immense potential to grow in low rainfall acreage are making them more popular. Out of these cumin (Cuminum cyminum) is more important crop as it have worth in international market. It is a winter season crop and is grown from mid of (October to November). The cumin overwhelmed in Indian kitchen due to its aroma and flavour. It is also used in preparation of seasonal bakery products as bread, Biscuits, etc. Apart from recipe whiff, it has medicinal significance and used as stimulant carminative, astringent stomachache and useful against dyspepsia (Verma, 2011).

Seed spices are upmost growing in Rajasthan and Gujarat states with little bit contribution of Madhya

\footnotetext{
How to cite this article: Bairwa, K.C., Meena, G.L., Meena, P.C. Burark, S.S., Singh, H., Upadhyay, B. and Chaplot, P.C. (2020). Sources of Growth and Variability in Production of Cumin in Jodhpur vis-à-vis Rajasthan. Economic Affairs, 65(4): 543-549.
}

Source of Support: None; Conflict of Interest: None 
Pradesh, Assam, West Bengal. Rajasthan state accounted about 6.29 lakh tones production of total seed spices from 8.33 lakh hectares area which is accounted for 48 per cent in area and 38 per cent in production of the country in 2018-19. The area and production of cumin in India was 10.27 lakh hectare and 6.99 lakh tones respectively, during 2018-19. Out of these, about 54 per cent area and 66 per cent production of cumin were contributed by Rajasthan state only (Anonymous, 2019-20). About 25 per cent area and 37 per cent production of total cumin in Rajasthan is contributed by Jodhpur district solely (DES, Rajasthan, 2019-20). Jodhpur district is having prime position in cultivated area and output of cumin in Rajasthan.

The commercial cultivation of cumin takes place in arid and semi arid region of the state. The good returns and higher cash value attract to every cultivator for its production. However, along with these attraction it is vastly perilous crop due to more fluctuation in climatic conditions attract to insectpest and diseases. Therefore, average farmers are not able to take huge amount of risk in the cultivation. The present study would provide a comprehensible understanding about growth and variability in acreage, output and yield of cumin at district and state level. Further, the decomposition analysis is explains to extent the contribution of yield, area and their combined contribution in production of cumin in Jodhpur district vis-à- vis Rajasthan. The present study is confined to Rajasthan state thus, the programmes and development strategies will be appropriate only for Rajasthan and especially arid regions.

\section{MATERIALS AND METHODS}

The present study is solely based on secondary information related to productivity, production and area of cumin. Purposively Based on highest output and cultivated land, Jodhpur district was selected to compare the relative performance of Rajasthan state in cumin production. For the present investigation, the study period from 1991-92 to 2018-19 is selected. For drawing consequential findings, selected study period is divided into three sub periods viz., Exante Agri-Export Zone from 1991-92 to 2004-05 (period-I), Ex-post Agri-Export Zone from 2005-06 to 2018-19 (period-II) and entire study period from 1991-92 to 2018-19 (period-III). The desired time series data on cultivated area, output and yield were compiled from various digital and non-digital sources of Government of Rajasthan as Directorate of Economics and Statistics, Agricultural Statistics at a glance and Jodhpur district land revenue department etc.

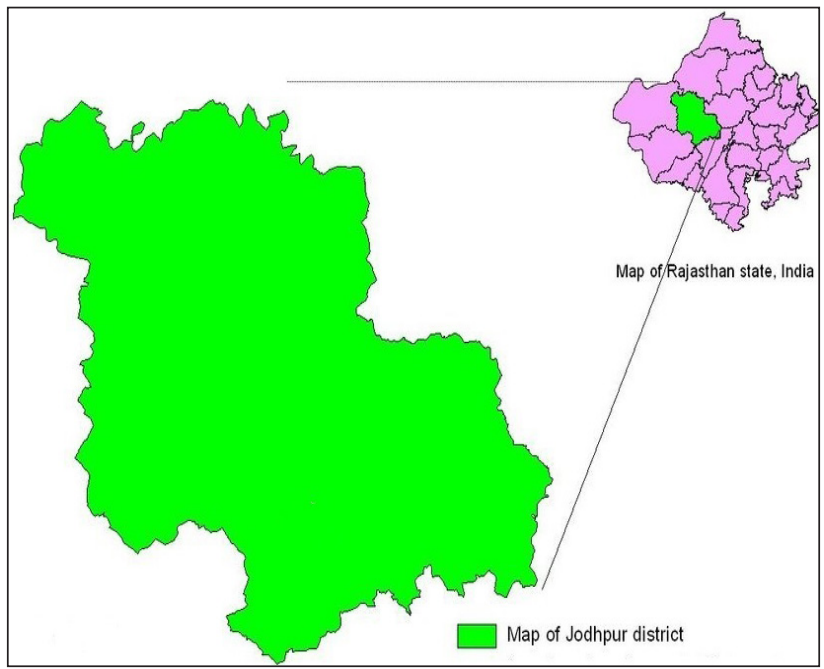

Fig. 1: Study area (Jodhpur vis-a-vis Jodhpur)

Statistical tools: The complied data on acreage, production and productivity were used to compute the growth, variability and sources of growth in cumin production. Hereby-statistical tools as exponential growth model, Cuddy-Della Valle instability index and decomposition model were used to obtain the objectives of the investigation, which are explained as given below:

Growth rate analysis: The production pattern of cumin was investigated by tabular analysis and compound annual growth rate (CAGR). Most probably, growth rate is calculated by linear and exponential models. When we use linear model, then it is results out only comparison of growth rate between crop(s) and time. This limitation, reduced selection of linear model to compute growth pattern. Many researchers Kumawat \& Meena, (2005); Dhakre \& Sharma, (2010); Bairwa, et al. (2012) and Sharma, (2013) were used exponential function for computation of growth rate in agricultural sector. Therefore, here we have used exponential model for computing growth rate of selected crop for all three periods. The exponential form of growth model is given as follow:

$$
Q t=a(1+r)^{t}
$$


Taking $\log$ on both sides of equation (1),

$$
\operatorname{Ln}\left(Q_{t}\right)=\ln (a)+t \ln (1+r)
$$

Where,

$Q_{t}$ is the area/production/yield of cumin in $\mathrm{t}^{\text {th }}$ period; $r$ is the compound annual growth rate of cumin and $\ln$ is the natural logarithm.

Now keeping,

$$
\begin{aligned}
& \operatorname{Ln}\left(Q_{t}\right)=y, \\
& \ln a=\alpha \text { and } \\
& \ln (1+r)=\beta
\end{aligned}
$$

So, the equation (2) becomes as,

$$
y=\alpha+\beta t
$$

Now, Ordinary Least Squares method is used to compute the value of coefficients $\alpha$ and $\beta$.

Further, Compound annual growth rate is computed as given below:

$$
r=\{\operatorname{antilog}(\beta)-1\} \times 100
$$

The SPSS statistical software was used to calculate the growth rate, $\mathrm{R}^{2}$ and standard error because it gives value of coefficients and significance directly.

Instability Analysis: To measure the variability and risk in production of agriculture sector, coefficient of variance, dynamic instability index and Cuddy Della Valle index are used. Out of these Cuddy and Della Valle instability index (Cuddy and Della Valle, 1978) is better as compared to CV and dynamic instability index, since it is innately adjusted for trend and often observed in time series. The instability in yield, output and cultivated area of cumin is calculated by using Cuddy-Della Valle instability index. The formula of Cuddy-Della Valle index is expressed as follow:

$$
I=C V \times \sqrt{\left(1-R^{2}\right)}
$$

Where,

$\mathrm{I}$ is the instability index (\%),

$$
C V=\frac{S D}{M e a n} \times 100
$$

$C V=$ is the coefficient of variation (\%), and $\mathrm{R}^{2}$ is the coefficient of determination from a time trend regression adjusted by the number of degrees of freedom.
Decomposition analysis: It is used to compute the relative contribution of factors as area and productivity in total output of individual pulse crop. Devi, et al. (2017); Ruchi, (2017); Kamble and Wali, (2016) and Bastine \& Palanisami, (1994) were applied component analysis model to examine the relative contribution of area and productivity in changing level of output. The general outline of decomposition model is expressed as:

$$
Q=C Y
$$

Where $Q=$ production of cumin in Rajasthan/ Jodhpur; $C=$ Cultivated area under cumin crop; $Y$ $=$ Yield of selected seed spice crop

$$
\begin{aligned}
& \text { Then, } Q_{0}=C_{0} Y_{0} \text { and } \\
& Q_{t}=C_{t} Y_{t}
\end{aligned}
$$

where 0 and $t$ is time periods such that $t>0$ by an accounting period (usually single year)

$$
\begin{aligned}
& \text { Now }\left(Y_{t}-Y_{0}\right)=\Delta Y_{t} \\
& \left(C_{t}-C_{0}\right)=\Delta C_{t} \\
& \left(Q_{t}-Q_{0}\right)=\Delta Q_{t}
\end{aligned}
$$

Now substituting the terms represented in (iv) equation into (iii) equation,

$$
\begin{aligned}
& Q t=\left(C_{0}+\Delta C_{t}\right)\left(Y_{0}+\Delta Y_{t}\right) \\
& \Delta Q_{t}=\left(Q_{t}-Q_{0}\right)=\left\{\left(C_{0}+\Delta C_{t}\right)\left(P_{0}+\Delta P_{t}\right)\right\}-C_{0} P_{0}
\end{aligned}
$$

or

$$
\Delta Q_{t}=\left(C_{0} \Delta P_{t}\right)+\left(P_{0} \Delta C_{t}\right)+\left(\Delta C_{t} \Delta P_{t}\right)
$$

$($ Change in production $)=$ Yield effect + Area effect + Interaction effect

Thus, the total change in production is attributed due to area and yield that can be decomposed into three effects viz., yield, area and interaction effects.

\section{RESULTS AND DISCUSSION}

The results of exponential trend line fitted in area, production and productivity of cumin in Jodhpur and Rajasthan were presented in table 1, fig. 1 and 2. It was revealed from the results that area and production of cumin was drastically increased, after the establishment of Agri-Export zone in the state. 
Table 1: Period-wise results of exponential $\left(Y=a \beta^{t}\right)$ trend line fitted for cumin in Jodhpur and Rajasthan

\begin{tabular}{llllll}
\hline \multirow{2}{*}{ Period } & \multirow{2}{*}{ Features } & \multicolumn{3}{c}{ Jodhpur } & \multicolumn{2}{c}{ Rajasthan } \\
\cline { 3 - 6 } & & $\alpha$ & $\beta$ & $\alpha$ & $\beta$ \\
\hline Period-I & Area & 10706.87 & 0.073 & 131417 & 0.044 \\
(1991-92 to 2004-05) & Production & 5461.521 & 0.037 & 50141.83 & 0.038 \\
& Yield & 510.349 & -0.036 & 381.548 & -0.006 \\
Period-II & Area & 18150.54 & 0.182 & 133578.4 & 0.123 \\
(2005-06 to 2018-19) & Production & 4577.342 & 0.261 & 30316.5 & 0.192 \\
& Yield & 252.067 & 0.079 & 226.958 & 0.068 \\
Overall Study Period & Area & 8040.379 & 0.104 & 113939.7 & 0.054 \\
(1991-92 to 2018-19) & Production & 2771.773 & 0.118 & 36689.38 & 0.064 \\
\hline
\end{tabular}

Source: Author's own computation using complied time series data

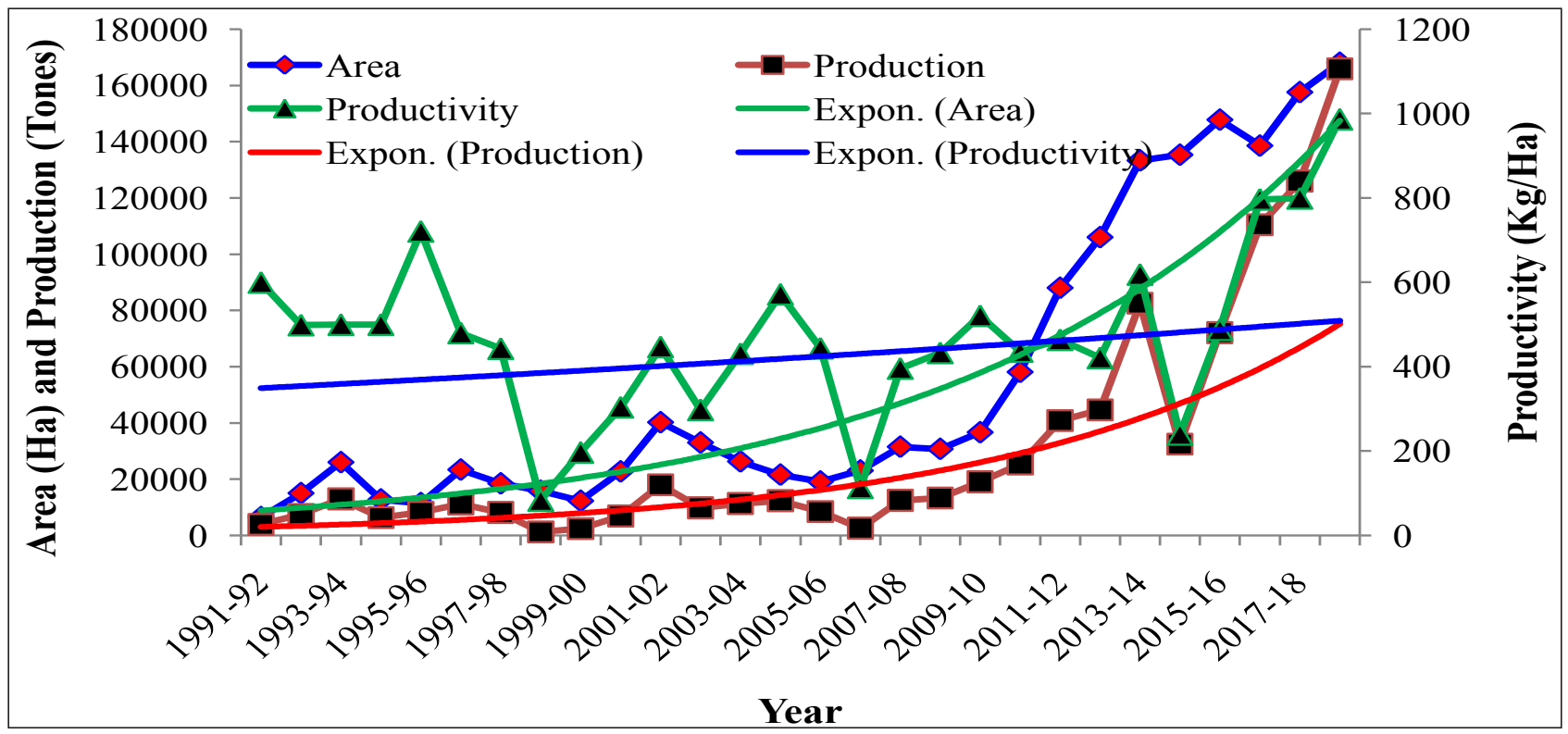

Fig. 1: Trend in Area, Production and Productivity of Cumin in Jodhpur

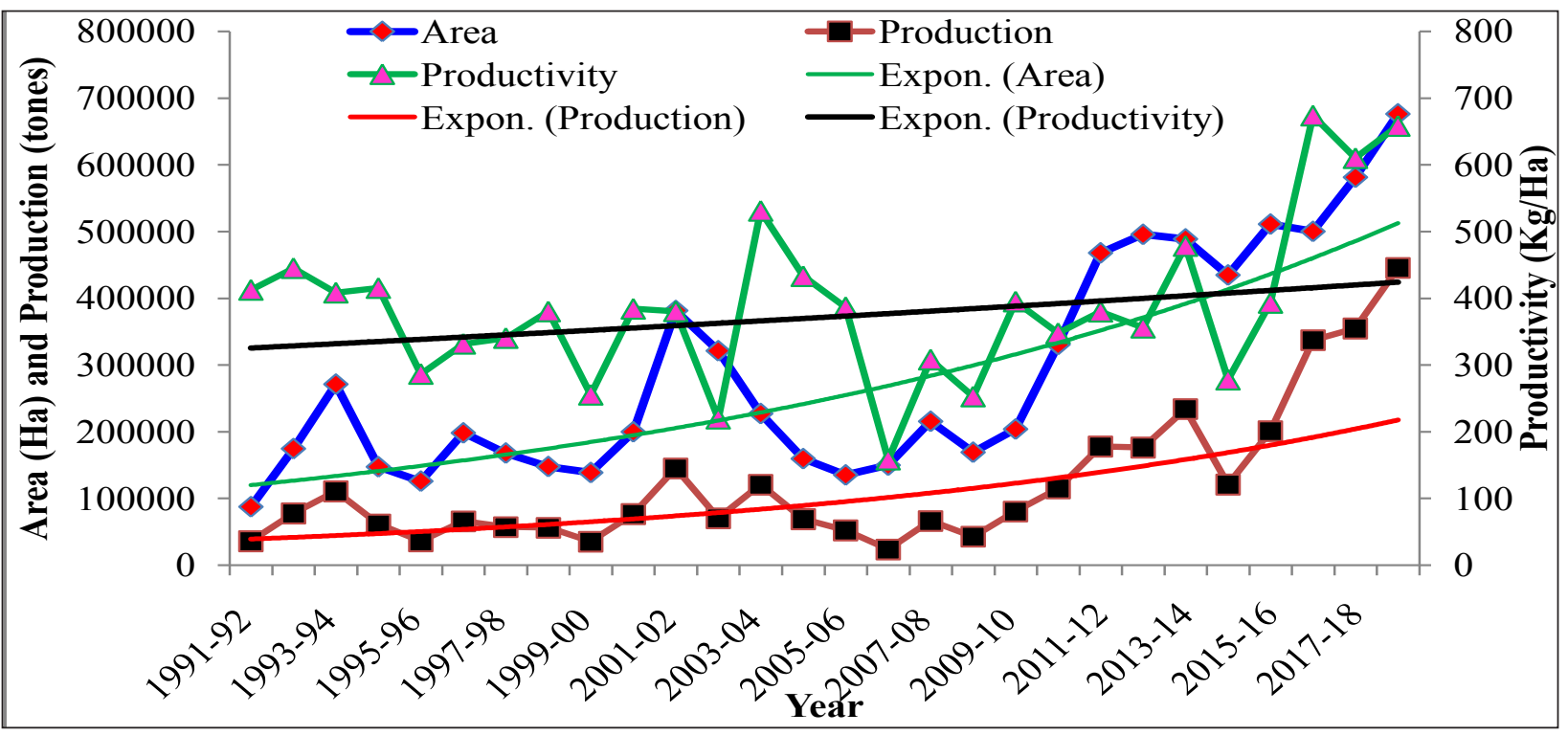

Fig. 2: Trend in Area, Production and Productivity of Cumin in Rajasthan 
The agri-export zone are attracting to growers for occupying more area under cumin crop particularly in Jodhpur district.

Assumed trend line of area, production and productivity is presented by curve lines in the figure. The value of area, production and yield associated with year presents to slope of the curve.

The trend analysis provides direction of change and rate of change in particular variable(s) during the studied period. However, it is unable to present the picture of per annum changing rate in particular variable. The positive trend coefficients of area, production and productivity for cumin were found in all periods in Jodhpur and Rajasthan, except yield in period-I. This negative trend in productivity might be due to off time and lower rainfall than average annual rainfall in Rajasthan. During periodII, the trend coefficient of production and area were positive and higher than period-I. After establishing of Agri-export zones, cumin has become important crop in this region.

Growth rate analysis: The compound annual growth rate analysis is taken to remove the limitation of trend analysis. The value of compound annual growth rate and $\mathrm{R}^{2}$ of acreage, output and yield of cumin is presented in table 2 . The results of CAGR indicated that the production of cumin in Jodhpur and Rajasthan was increased about 3.8 per cent per annum in period-I. During same period, the area under this crop in Jodhpur was increased at 7.57 as compared to 4.5 per cent per annum in Rajasthan. The area under this crop in Jodhpur was increased because it is an important cash crop of the district but its cultivation is highly sensitive with the change in weather conditions and incidence of insect pests \& diseases. Farooq et al. (2005) reported a negative growth rate in production of cumin in Rajasthan due to more frequency of wilt, blight and powdery mildew and drought conditions. Afterwards, the establishment of Agri-export Zones, area and production of this crop was drastically expanded in Jodhpur along with Rajasthan. During period-II, the yield, area and production of cumin in Jodhpur district were increased at positive significant rate of 8.22, 19.96 and 29.82 per cent per annum, respectively. At the same time, the growth performance of cumin in the state was slightly smaller than Jodhpur. It is also concluded from the table 2 that during overall study period, area and output of cumin at state level showed significant positive growth rate of 5.54 and 6.60 per cent per annum which was lesser than Jodhpur. After set up of the Agri-export Zones of seed spices in the country, the output of this crop was increased due better productivity, development of high yielding varieties and increasing importance of cumin in international spice market. In the same way, Somya, et al. (2014) reported positive significant growth rate in cumin at national level.

Instability index analysis: The instability in production of cumin crop for all three periods is

Table 2: Compound annual growth rate, $\mathrm{R}^{2}$ and standards errors value of Exponential function in area, production and yield of cumin in Jodhpur district and Rajasthan

\begin{tabular}{llllll}
\hline \multirow{2}{*}{ Study Period } & \multirow{2}{*}{ Crops } & \multicolumn{3}{c}{ Jodhpur } & \multicolumn{2}{c}{ Rajasthan } \\
\cline { 3 - 6 } & & CAGR & $\mathbf{R}^{2}$ & CAGR & $\mathbf{R}^{2}$ \\
\hline Period-I & Area & $7.57^{*}(0.384)$ & 0.407 & $4.50_{\text {NS }}(0.355)$ & 0.225 \\
$\mathbf{( 1 9 9 1 - 9 2 ~ t o ~ 2 0 0 4 - 0 5 )}$ & Production & $3.76_{\text {NS }}(0.718)$ & 0.048 & $3.87_{\text {NS }}(0.424)$ & 0.131 \\
& Yield & $-3.54_{\text {NS }}(0.554)$ & 0.074 & $-0.60_{\text {NS }}(0.243)$ & 0.012 \\
Period-II & Area & $19.96^{*}(0.232)$ & 0.921 & $13.08^{*}(0.209)$ & 0.869 \\
(2005-06 to 2018-19) & Production & $29.82^{*}(0.438)$ & 0.871 & $21.16^{*}(0.349)$ & 0.851 \\
& Yield & $8.22^{*}(0.438)$ & 0.384 & $7.03^{*}(0.28)$ & 0.53 \\
Overall Study Period & Area & $10.96^{*}(0.397)$ & 0.828 & $5.54^{*}(0.356)$ & 0.615 \\
$\mathbf{( 1 9 9 1 - 9 2}$ to 2018-19) & Production & $12.52^{*}(0.754)$ & 0.632 & $6.60^{*}(0.551)$ & 0.483 \\
& Yield & $1.40_{\text {NS }}(0.538)$ & 0.045 & $1.00_{\text {NS }}(0.313)$ & 0.065 \\
\hline
\end{tabular}

Figure in parenthesis is standard error.

Source: Author's own computation based on compiled time series data

Note: *Statistically Significant @ 1\% andNS = Non-significant 
Table 3: Variability in area, production and yield of cumin in Jodhpur district and Rajasthan

\begin{tabular}{|c|c|c|c|c|c|c|}
\hline \multirow{2}{*}{ Study Period } & \multicolumn{3}{|c|}{ Rajasthan } & \multicolumn{3}{|c|}{ Jodhpur } \\
\hline & Area (\%) & Production (\%) & Yield (\%) & Area (\%) & Production (\%) & Yield (\%) \\
\hline $\begin{array}{l}\text { Period-I } \\
\text { (1991-92 to 2004-05) }\end{array}$ & 37.511 & 43.51 & 22.60 & 35.75 & 52.64 & 38.36 \\
\hline $\begin{array}{l}\text { Period-II } \\
\text { (2005-06 to 2018-19) }\end{array}$ & 17.56 & 30.00 & 26.79 & 32.90 & 45.92 & 111.68 \\
\hline $\begin{array}{l}\text { Overall Study Period } \\
\text { (1991-92 to 2018-19) }\end{array}$ & 36.19 & 63.10 & 30.60 & 40.47 & 82.78 & 42.08 \\
\hline
\end{tabular}

Source: Author's own computation from complied statistical data.

Table 4: Period wise decomposition of growth in cumin production of Jodhpur and Rajasthan

\begin{tabular}{lllllll}
\hline Period & \multicolumn{2}{c}{$\begin{array}{c}\text { Period-I } \\
\text { (1991-92 }\end{array}$} & \multicolumn{2}{c}{$\begin{array}{c}\text { Period-II 2004-05) } \\
\text { (2005-06 to 2018-19) }\end{array}$} & \multicolumn{2}{c}{$\begin{array}{c}\text { Overall Study Period } \\
\text { (1991-92 to 2018-19) }\end{array}$} \\
\hline Study area & Jodhpur & Rajasthan & Jodhpur & Rajasthan & Jodhpur & Rajasthan \\
\hline Yield Effect (\%) & 4.37 & 25.88 & 92.00 & 37.15 & 46.92 & 35.96 \\
Area Effect (\%) & 97.25 & 77.97 & 0.12 & 56.01 & 48.82 & 57.51 \\
Interaction Effect (\%) & -1.62 & -3.85 & 7.88 & 6.84 & 4.26 & 6.53 \\
\hline Change in output & $\mathbf{1 0 0}$ & $\mathbf{1 0 0}$ & $\mathbf{1 0 0}$ & $\mathbf{1 0 0}$ & $\mathbf{1 0 0}$ & $\mathbf{1 0 0}$ \\
\hline
\end{tabular}

Source: Author's own computation based on compiled time series data.

worked out and presented in table 3 . The value of instability presents in three categories viz., low (0 to 15), moderate (15.1 to 30) and high instability (above 30). It is revealed from the results of variability that production of cumin in Jodhpur and Rajasthan was highly instable at 52.64 and 43.51 per cent, respectively, in period-I. during same period, the instability in area and yield of the crop were found at moderate rate. The instability in area, production and yield of cumin in Jodhpur was reported at 32.90, 45.92 and 111.68 per cent followed by Rajasthan at $17.56,30.00$ and 26.79 per cent respectively, during period-II.

The upmost instability of $40.47,82.78$ and 42.08 per cent in area, production and productivity was recorded in Jodhpur for the overall study period. Alike Jodhpur, higher instability in acreage, output and productivity of the same crop is also reported for the overall study period. During period-II, more than 100 per cent instability index in yield indicated that production of cumin was increase mainly due to increase in productivity of the crop. The National Research Centre on Seeds Spices, Ajmer and other state agricultural universities are playing important responsibility for development of good operational management practices and high yielding varieties with high essential oil content and resistance to biotic and abiotic stresses. Similarly, Kumawat and Meena (2005) also observed higher degree of instability for cumin in Rajasthan during PostTechnology Mission on Oilseeds (TMO).

Sources of output growth: The analysis of growth rate in productivity, production and area of cumin observed an expanding growth and direction of alters in area and productivity. Nevertheless, this analysis does not provide any information on contribution of area and productivity towards the output growth of cumin. Consequently, it is compulsion to estimate the factors responsible for growth in production.

The period wise relative contribution of productivity and area in changing production of cumin is computed and displayed in table 4 . The periodwise results of de-composition analysis showed that during period-I, most of the output growth was in cumin was added by expanding area in Jodhpur and Rajasthan at 97.25 and 77.97 per cent respectively. during period-II, the major contribution of area (92.00 per cent) and yield (56.01) in output growth was recorded in Rajasthan and Jodhpur respectively. Whereas the area contribution for the overall study period was only 48.82 per cent and 57.51 per cent 
at district and state, level respectively. Similarly, Das (2016) also reported that expansion in area is major source of output growth in spices in NorthEast India.

\section{CONCLUSION}

The yield, production and area under cumin is showing increasing trend over the time. Therefore, stress should be given on promotional activities/ schemes to expand the area of cumin. The variability in production of the crop is mainly due to increase in the yield. This yield effect help to expand the area under cumin. However, its price is very volatile in Indian market. Therefore, appropriate measures should be acquired by the Central and State Government to stabilize the price and save the interest of cumin growers such as announcement of the minimum support price, schemes and processing development programmes.

\section{ACKNOWLEDGEMENTS}

The authors are thankful to the Agriculture University, Jodhpur, Rajasthan for its pecuniary and ethical support to conduct this research study. Moreover, the authors are also indebted to the Department of Agricultural Economics \& Management, Rajasthan College of Agriculture, Maharana Pratap University of Agriculture and Technology, Udaipur, Rajasthan-India for their positive suggestions that helped to improve the content of this study.

\section{REFERENCES}

Bairwa, K.C., Sharma, R. and Kumar, T. 2012. Economics of growth and instability: Fruit crops of India. Rajasthan Journal of Extension Education, 20: 128-132.

Basitine, C.L. and Palanisami, K.P. 1994. An analysis of growth trends in principal crops in Kerala. Agricultural Situation in India, 48(12): 885-891.
Cuddy, J.D. and Valle, P.A.D. 1978. Measuring the instability of time series data. Oxford Bulletin of Economics and Statistics, 40:53-78.

Das, K. 2016. Production conditions of spices in North-East India: Cases of ginger and chilli. Discussion Paper No. 51, Centre for Development Studies, Thiruvananthapuram, Kerala.

Devi, Y.L., Arivelarasan, T. and Kapngaihlian, J. 2017. Pulses production in India: Trend and decomposition analysis. Economic Affairs, 63(3): 435-438.

Dhakre, D.S. and Sharma, A. 2010. Growth and instability analysis of ginger production in North-East Region. Agricultural Science Digest, 30:142-147.

Farooqi, A.A., Sreeramu, B.S. and Srinivasappa, K.N. 2005. Cultivation of spices crops. University Press Pvt. Ltd., Hyderabad, India.

Kamble, A.S. and Wali V.B. 2016. Dynamics of horticulutral crops in Karnataka an hazel decomposition analysis. Indian Journal of Applied Research, 6(8): 119-122.

Kumawat, R.C. and Meena, P.C. 2005. Growth and instability in area, production and yield of major spice crops in Rajasthan vis-à-vis India. Journal of Spices and Aromatic Crops, 14(2): 102-111.

Ruchi 2017. Food grains in India: Growth, instability and decomposition analysis. International Journal of Multidisciplinary Research and Development, 4(6): 304-308.

Sharma, A. 2013. Trends of area, production and productivity of Food grain in the north eastern states of India. Indian Journal of Agricultural Research, 47: 341-346.

Soumya, C., Burark, S.S., Sharma, L. and Jain, H. K. 2014. Growth and instability in production and export of selected spices of India. International Journal of Seed Spices, 4(2): 1-10.

Verma, V.K. 2011. Production and marketing of cumin in Jodhpur district of Rajasthan. Un-published M.Sc. (Agricultural economics) Thesis, Rajasthan University of Bikaner, Campus-Jobner. 
